\title{
Leadership in the French Navy during the Revolution and Empire. The Optimist and the Pessimist: Louis-René de Latouche- Tréville (1745-1804) and Pierre Charles de Villeneuve (1763-1806)
}

\author{
Rémi Monaque \\ Marine française
}

The Revolution of 1789 brought about a profound and lasting disorganisation of the French navy. Its officer corps, mostly consisting of nobles, was forced to take part in a massive emigration. Some of them, due to family traditions, considered their fidelity to the King more important than their fidelity to the Nation, but many, although open to new ideas, left the country just to save their lives. The awful atmosphere that existed on board ships made it impossible for them to exercise authority over their crews who had lost all confidence in the 'aristocrats' whom they suspected of betrayal. Some rare noble officers managed to stay in service for a while. However, by November 1793 they were all dismissed. After the Reign of Terror, which ended in 1794, successive governments started the reintegration of the old noble officer corps but this procedure

\section{How to cite this book chapter:}

Monaque, R. 2017. Leadership in the French Navy during the Revolution and Empire. The Optimist and the Pessimist: Louis-René de Latouche-Tréville (1745-1804) and Pierre Charles de Villeneuve (1763-1806). In: Harding, R and Guimerá, A (eds.). Naval Leadership in the Atlantic World. Pp. 99-106. London: University of Westminster Press. DOI: https://doi.org/10.16997/book2.j. License: CC-BY-NC-ND 4.0 
concerned only a limited number of individuals. To solve the problem of the huge lack of officers, all kinds of improvisations were necessary. Many officers of the merchant marine were enrolled and the best qualified petty officers in the navy promoted. But these measures had their limits, all the more so as the elementary training of young officers was no longer assured since the suppression of companies of Gardes Marine by the Revolution. One had to wait till 1810 to see the rebirth of schools for officers. Besides, the French squadrons, weakened by the defection of their best-trained officers and the complete disorganisation of naval dockyards, now found themselves hampered by the superiority of the Royal Navy against which it had battled on equal terms during the American War of Independence. Moreover, the handover by the Royalists of the port of Toulon to the Anglo-Spanish forces in 1793 had cost the French navy 13 vessels, that is to say, a loss exactly equal to that suffered at Trafalgar. All this explains why the Revolutionary and then the imperial navy was completely dominated by its ancient adversary and spent most of its time in harbours blocked by the British navy.

Serious training and the opportunity of forming new, competent commanders was not possible. Very often, it is among the old sailors of Louis XVI's navy, survivors of the Revolution, that one has to look for admirals capable of conducting effective operations. Two examples concern us in this paper - one happy and successful, that of Louis-René de Latouche-Tréville, who has left a bright and unforgettable reputation in the French navy. The other, that of Pierre Charles de Villeneuve, a profoundly sad character, who is linked to the most tragic event known to the French navy.

Latouche-Tréville (1745-1804) was from a family ennobled in the reign of Louis XIV for work accomplished in the West Indies at the beginning of French colonisation. From this colonial past, the future admiral, himself the son of one of the King's naval officers, inherited a spirit of adventure, a great capacity for speaking without constraint and a total absence of prejudice. All his life, Latouche had a network of friendly relationships with people of all conditions, from the princes of royal blood to his village carpenter. He had a great love for his profession and his country, but no political convictions whatsoever. He served all the regimes with the same enthusiasm and, from being a good royalist, became a convinced Jacobin and then a devoted subject of the Emperor without the slightest remorse. He is one of the rare officers of the nobility who succeeded in retaining the confidence of his crews during the campaign, in the Mediterranean Sea, of the first squadron which sailed under the Republican flag (October 1792-March 1793). He had just been promoted to the rank of chef d'escadre (Rear Admiral) and, far from being offended by observing the growth of committees of seamen, he took advantage of them to influence the morale of the crews. By giving loyal Republican instructions, he used the committees to spread confidence in him, his ideas and his orders. On his flagship, Languedoc, Latouche overcame without 
difficulty the crew's attempt at rebellion by appealing to the patriotic feelings of the mutineers.

Louis-René was one of those rare naval officers who knew how to exercise their uncontested authority while, at the same time, being adored by their crews and their officers. He showed in a brilliant fashion that a chief need not be harsh and unpleasant in order to be obeyed. His good humour, optimism and benevolence brought him results far superior to many of his peers who were satisfied with cold severity. Jurien de La Gravière, one of Latouche's subordinate officers, relates in his memoirs how he became forever attached to this admiral. ${ }^{195}$ In 1802, at Rochefort, Jurien commanded a frigate in the squadron sailing out to Saint-Domingue and, on the first day of his service, he made a grave error in manoeuvring under the eyes of the admiral, which he managed to correct brilliantly. He writes:

'Latouche was an accomplished seaman and the least movement of his squadron did not escape his observation. Far from blaming me, he had the kindness to congratulate me for the manoeuvre with which I had got back from a difficult situation. From that day onwards, my heart was his. I felt I had just met a man worthy of commanding French officers and sailors'.

Latouche's benevolence extended even to his enemies. Louis-René was one of those eighteenth-century men who engaged in warfare without hatred, considered their adversaries as colleagues doing the same job, maintained courteous relationships with them during the conflict and, once peace was re-established, could become their friends. Twice in his career, Latouche was able to congratulate himself for having adopted such an attitude. Taken prisoner, in the last months of the American War of Independence, by the Commodore Keith Elphinstone, after having scuttled his frigate on the American coast, LouisRené became a friend of his gaoler, was received by him in England and ended up by asking him to get him a two-seat coach (pretty without being splendid) for which he did not want to spend more than 40 Guineas! Later, in the course of the terrible Campaign of Saint-Domingue (1802-3), Latouche owed his survival to the quality of the relationship he had established with Admiral Duckworth, the commander of the naval forces of neighbouring Jamaica. The two men, without ever having met each other, had exchanged letters and presents and had soon come to feel mutual appreciation and friendship. The war having begun again in March 1803, Duckworth, learning that Latouche was dying, gave him permission to go back to France on a treaty vessel. This very kind action reminds us of the favour of which Admiral Rodney was the beneficiary, imprisoned for debt in Paris at the beginning of the War of Independence and freed thanks to the generosity of his French friends who must therefore take the responsibility for our defeat at the Saintes! 
Latouche-Tréville, who distinguished himself during the War of Independence as commander of several frigates, is the only French admiral who could boast that he kept Nelson at bay. In August 1803, while he was at the head of the Boulogne flotilla, he drove back on two occasions the attempts of the British hero to destroy or capture little landing ships moored off Boulogne. The second attempt, at night between 15 and 16 August, ended in a bloody failure. The destinies of Nelson and Latouche crossed once again, a third time, on 16 June 1804 off Toulon. On that day, Nelson, who had five ships and two frigates, decided to capture two French vessels moored at the north of Porquerolles. Latouche, who observed the manoeuvre from the Cape Cepet observatory, immediately ordered his squadron to get under way and left the port with his eight vessels at record speed. Nelson retired, followed by Latouche, till nightfall. This nonevent led to a report that pleased the First Consul Napoleon Bonaparte and was published in the official journal. It didn't take long for Nelson to become aware of it and he flew into a towering rage. He wrote to the whole world to defend himself against the charge of fleeing before the enemy and used many insulting expressions against Latouche, to whom he swore he would make him eat his report after having imprisoned him. Did the great man sometimes lack humour and a sense of fair play? As for Latouche, he did not feel any hatred for his adversary and spoke in his letters of his great desire to have another confrontation with his colleague, Nelson' - a striking difference of character but also of mentality between the two men. Nelson had in his heart, from the time of his youth, a hatred of the French. This feeling was exacerbated by the ideological passions that inspired the admiral. Since the beginning of the revolutionary wars, Nelson made war not only against his country's enemies but also against regicidal and irreligious Republicans.

The death of Latouche in August 1804 brought an end to the Homeric duel between the two champions. Louis-René, exhausted by his campaigns and the fervour to which he had had recourse in order to train his squadron in Toulon for combat, died of sickness in the harbour of Toulon on board his admiral flagship, Bucentaure, after having refused to be transported on land: 'A sailor', he had said, 'is only too happy to die under his flag.' His demise deprived Napoleon of his finest asset for conquering Great Britain. Latouche, to whom the Emperor had confided the principal role in his great strategy of invasion, believed in his mission and had already succeeded in building up his squadron's morale and was preparing it for the decisive confrontation. The friendly and even affectionate relationship which Louis-René had developed in Brest in 1800 with the Spanish Admiral Federico Gravina would have been a valuable asset during the manoeuvres of the campaign of $1804-5$, in the course of which Franco-Spanish cooperation would become essential.

Finding a substitute for Latouche at the head of the squadron of Toulon was a very difficult problem for the Emperor. The number of admirals capable of succeeding Nelson's former 'challenger' was extremely limited. Bruix had certainly 
acquired a great reputation but bad health made it impossible for him to do service at sea. Ganteaume, who had brought back Napoleon from Egypt and who, since then, had played the role of naval adviser to the head of state, was already appointed Commander of the squadron in Brest, that also had an important role to play in the Emperor's plans. Decrès, the minister of the navy, excluded Missiessy, a man of great worth but whom he did not like, and proposed the name of Villeneuve, who, lacking ambition, was not a threat to his ministerial career.

Villeneuve, 42 years old at that time, was from one of the oldest and most illustrious noble Provençal families. He entered the Company of the Naval Guards of Toulon in 1778 and fought throughout the American War of Independence, experiencing with Grasse the glory of the Battle of Chesapeake (5 September 1781) and the setbacks at the Battle of the Saintes (12 April 1782). At the time of the Revolution, he held the rank of lieutenant. His family, well-established in High Provence, approved of the new ideas and did not emigrate. He, like Latouche-Tréville, managed to remain in service and had the advantage of a rapid promotion. Like all officers from the nobility, he was excluded from the navy for a short period (November 1793-May 1795) during and after the Terror. After the Reign of Terror, his rise was phenomenal, all the more so as the other contenders were weak and he was endowed with exceptional advantages: a remarkable intelligence and lucidity, great professional qualities, an affable and benevolent character, and an exemplary sense of duty. Promoted to the rank of Rear Admiral from September 1796, Villeneuve commanded the rearguard of the French squadron at the Battle of the Nile (1 August 1798). He was not attacked by Nelson and witnessed the destruction of the rest of the squadron without making any attempt to come to their aid. To justify this passivity, Villeneuve attributed his action to contrary winds and the delays in making way. It was only on the following morning that he left the port and managed to take his division safe and sound to Malta. Far from being blamed, he was praised by the French government, the Directory, for having saved from disaster a section of the French fleet. As for Bonaparte, the event made him remember the fact that Villeneuve was a lucky man, which, to his mind, was a considerable advantage. The Admiral, however, was traumatised by what happened and continued to have a deep sense of inferiority when faced with Nelson's genius. He had no wish to undergo another confrontation with this 'colleague'.

When, in Autumn 1804, the squadron trained by Latouche-Tréville was put under his command, Villeneuve felt there was an unbearable burden on his shoulders. He showed himself absolutely incapable of maintaining the activity, the confidence and the high state of morale that his predecessor had succeeded in developing. ${ }^{196}$ On the other hand, his solitary reflections permitted him to guess, with extraordinary foresight, what a confrontation with Nelson would be like. In the instructions he sent to his captains on the 21 December 1804, Villeneuve wrote with exactitude what the Battle of Trafalgar would be: 
'The enemy will not stop at creating a battle line parallel to ours and at delivering an artillery battle [ ... ]. He will seek to surround our rear guard, to cross us and carry his own divisions upon those vessels of ours that he will have separated, in order to surround and reduce them.'

The tragic aspect of Villeneuve is that this rare lucidity was accompanied by a profound pessimism. He believed that the French and soon the Spanish ships he would have to deal with would be incapable of performing complicated manoeuvres and he would have to be satisfied with opposing the enemy with a line of vessels tightly closed up to one another. His first attempt to get under way from Toulon in January 1805 convinced him of the validity of this opinion. The violent gust of the Mistral that he was subjected to as he got out of the port caused such a state of disorder in his squadron that he was obliged to return shamefully three days later. In despair, he wrote to Decrès, the minister of the navy, a profoundly defeatist letter in which there is this terrible sentence: 'The enemy will beat us even with forces inferior to ours by a third.' Following the logical conclusion of this analysis, Villeneuve declared his resignation. The minister then committed an unforgivable mistake: he did not send the letter to the Emperor and asked his friend to remain at his post. Villeneuve, in the spirit of duty, but also as someone who was passive and resigned to his fate, agreed to pursue his mission. A man afflicted with two such serious faults as pessimism and passivity should never have been invested with a such a command.

Without the space to explore all the events of the campaign that preceded Trafalgar, let us simply note a few episodes that illustrate Villeneuve's style of command and his temperament. The French squadron left Toulon on 30 March 1805. It sailed through the Strait of Gibraltar without opposition and arrived on 9 April in Cádiz where it was to be joined by a Spanish squadron. Only the Argonauta, the flagship of Admiral Federico Gravina, and the French vessel L'Aigle were in the port and ready to leave. Villeneuve stayed only a few hours in the harbour and sailed away towards the West Indies without waiting any longer for the five Spanish vessels which were not ready to sail out. This haste has something indecent about it for it shows quite plainly the pathological fear he had of a confrontation with the victor of Aboukir. It could only have been perceived as a negative quality by the French crews and even more by his Spanish allies. Once he arrived in Martinique, Villeneuve, in conformity with the orders received, waited 40 days for the rallying of the squadrons of Brest and Rochefort. This useless waiting, during which he could take no major action against the enemy ${ }^{197}$ brought upon him the lively reproaches of the Emperor. The Admiral was hurt by this profoundly unjust criticism and his morale was affected. After recrossing the Atlantic he met the squadron of Rear Admiral Sir Robert Calder off the western coast of Spain on 22 July 1805. An indecisive action followed. The day after this battle Villeneuve lost precious time putting his squadron into order instead of pursuing the enemy vigorously and retaking 
the two Spanish vessels captured by Calder. This failure was another blow to his morale as indeed it was to the rather uncertain prestige he enjoyed among his Spanish allies. Finally, on 15 August, while he had succeeded in joining the Spanish squadron in Ferrol, Villeneuve, completely demoralised, abandoned his voyage towards Brest in order to take refuge in Cádiz. He believed, not without good reason, that the enemy had now been able to concentrate important forces at the entry of the English Channel and that his own mission had become quite impossible.

To sum up, the West Indian campaign was a long Calvary for Villeneuve. His morale, faltering from the beginning, sank further without the Admiral being able to find the necessary energy and optimism to train his men and prepare them for a decisive combat. The great accomplishments at Trafalgar by several French and Spanish vessels show, however, that there was, in the Franco-Spanish squadron, a potential that Villeneuve did not know either how to mobilise or to federate. Resignation, pessimism and passivity do not make great commanders! There certainly was too great a difference between the combined fleet and its British adversary to hope for a victory. The precision and rapidity of firing, the monopoly of carronades, terribly efficient at short distances, but, above all, the formation and training of the crews gave the British an advantage that could not be equalled. But the terrible tragedy of Trafalgar, for which Napoleon was chiefly responsible, could have been avoided. Let us remember that on 19 October 1805, the united fleet sailed from Cádiz not in order to conquer England but to reach Toulon. Let us keep in mind the fact that if Villeneuve was still at the head of the fleet, it was because the Emperor had taken the demented decision of sending a substitute for Villeneuve without informing him, thinking that the Admiral, too faint-hearted, would not dare to attack the enemy. In fact, Villeneuve was a courageous man who believed he could redeem himself only by a brilliant performance or by dying worthily.

In the end, his adversaries rendered him deep respect. Rather naively, the English officers who came across him during his captivity were surprised to meet not the slovenly and vociferous individual they expected but a very distinguished gentleman; Admiral Collingwood presents a fine portrait: ${ }^{198}$ 'Admiral Villeneuve is well brought-up and, I believe, a very good officer; there is nothing displeasing or boastful, such as we attribute too often to the French, in his behaviour.' In short, in the eyes of the English, Villeneuve was someone very easy to associate with, who even possessed abundantly the quality of fair play. What better, in fact, than to be beaten while showing consistent resistance in order to assure the glory of one's conqueror?

The admirals of the Revolution and of the Empire had the unrewarding task of combating, in terribly unfavourable circumstances, an enemy who had attained great superiority. In the first years of the Revolution, they sailed out to combat with improvised captains, crews often on the verge of mutiny, and ships badly maintained and lacking armaments. Later, when order was restored on 
board ship and in the naval dockyards, British supremacy was such that French squadrons, blocked in ports, had huge difficulties in acquiring a minimum of training, all the more as the seamen who had been well trained were in a state of exhaustion. Napoleon's style of command did not improve the situation. Not having confidence in his admirals, the Emperor did not inform them of the objectives he had in mind but overwhelmed them with orders containing precise details and the threat of imposing sanctions in case of laxity or disobedience, which, taking into account communication delays, no longer had anything to do with the present situation and became a source of trouble and confusion.

In these circumstances, the talents that existed outside the noble corps of the Naval Guards had neither the time to blossom nor the possibility of doing so. Certain admirals, such as Villaret-Joyeuse and Allemand, former auxiliary officers, or Martin, former petty officer in the Royal Navy, showed real qualities which could at other times, have produced great commanders. LatoucheTréville, who defied his colleague Nelson, and Villeneuve, who was tragically trapped while performing a role he knew himself incapable of assuming, still belonged to the great navy established in the time of Louis XVI. 